\title{
ANALISIS MONITORING ARUS DAN TEGANGAN PADA TARIF R1-TR MENGGUNAKAN MIKROKONTROLER ATMEGA 328
}

\author{
Agus Pramono', Abdul Azis², Youngky Ricky A.W ${ }^{3}$ \\ Program Studi Teknik Informatika, STMIK Amikom Purwokerto
}

\begin{tabular}{l} 
Informasi Makalah \\
\hline Dikirim, 15 Oktober 2018 \\
Direvisi, 03 Januari 2019 \\
Diterima, 30 April 2019 \\
\end{tabular}

\section{Kata Kunci:}

Arduino 328,

Mikrokontroler

Sistem Tenaga Listrik,

Beban

\section{Keyword:}

Arduino 328

Microcontroller,

Electric Power Systems,

Load

\begin{abstract}
INTISARI
Salah satu manfaat yang sangat menunjang peranan mikrokontroller adalah implementasi dalam bentuk modul dan sistem kontrol pada penerapan teknologi industri. Sistem pemantauan tegangan dan arus bertujuan untuk memudahkan pemantuan pada jaringan intalasi listrik sehingga dapat diketahui besar kecilnya penggunaanya. Mikrokontroler sebagai unit prosesor yang akan terintegrasi ke sensor dan komponen elektronika yang digunakan sebagai pembaca inputan dari sensor yang kemudian akan dimonitoring baik secara manual dan digital. Untuk itu dibuatkan media protype untuk memonitoring tegangan dan arus dapat dipantau beban yang digunakan pada saat beban normal dan beban puncak, hal ini dikarenakan untuk menghindari terjadinya arus dan tegangan lebih pada suatu instalasi listrik, sehingga beban penampang penghantar tidak melampui batas yang sudah ditentukan dan dapat mengakibatkan kebakaran pada instalasi listrik tersebut.
\end{abstract}

\begin{abstract}
One of the benefits that greatly supports the role of microcontrollers is the implementation in the form of modules and control systems in the application of industrial technology. The voltage and current monitoring system aims to facilitate monitoring of the electrical installation network so that it can be known for its small size. The microcontroller as a processor unit will be integrated into sensors and electronic components that are used as input readers from sensors which will then be monitored both manually and digitally. For this purpose, a prototype media is made to monitor the voltage and current that can be monitored by the load used during normal load and peak load, this is due to avoiding the occurrence of overcurrent and overvoltage in an electrical installation, so that the load crossing load does not exceed the specified limit and can resulting in a fire in the electrical installation.
\end{abstract}

\section{Korespondensi Penulis:}

Agus Pramono

Program Studi Teknik Informatika, STMIK Amikom Purwokerto

Jl. Let. Jend. Pol. Sumarto, Purwokerto

Email: agus@amikompurwokerto.ac.id

\section{PENDAHULUAN}

Energi listrik merupakan salah satu kebutuhan masyarakat yang sangat penting dan sebagai sumber daya ekonomis yang paling utama yang dibutuhkan dalam berbagai kegiatan sehari-hari. Dalam waktu yang akan datang kebutuhan listrik akan terus meningkat seiring dengan adanya peningkatan dan perkembangan baik dari jumlah penduduk dan jumlah investasi. 
Pembangkit listrik yang memanfaatkan kondisi alam, menyebabkan energi listrik yang dihasilkan sangat fluktuatif tergantung pada kondisi cuaca. Tegangan dan arus pada jaringan instalasi listrik biasanya kurang stabil, maka dibutuhkan sistem monitoring pada jaringan tersebut untuk memantau besarnya tegangan dan arus yang diterima. Untuk itu dibuatkan prototype sebagai alat pemantauan atau monitoring terhadap tegangan dan arus yang terpakai pada saat beban normal dan beban pucak sehingga dapat diketahui berapa besar tegangan yang disalurkan dan berapa arus yang terpakai pada saat pemaikan dalam kondisi beban puncak.

Hal ini perlu diketahui bahwa pada tarif R1-TR yang dikeluarkan oleh PLN (Perusahaan Listrik Negara) adalah Daya 450 VA sampai dengan Daya 2200 VA dari jenis pelanggan pascabrayar maupun pelanggan prabayar, hal ini dari semua pelanggan pascabrayar dan prabayar masih mengabaikan untuk memonitoring tegangan dan arus pada daya listrik yang terpasang.

Sistem pemantauan tegangan dan arus bertujuan untuk memudahkan pemantuan pada jaringan intalasi listrik sehingga dapat diketahui besar kecilnya penggunaanya. Mikrokontroler sebagai unit prosesor yang akan terintegrasi ke sensor dan komponen elektronika digunakan membaca inputan dari sensor tersebut.

\section{METODE PENELITIAN}

Kerangka pemikiran adalah sebuah model konseptual tentang bagaimana teori berhubungan dengan berbagai faktor yang telah di identifikasi sebagai hal yang penting dalam bentuk proses dari keseluruhan penelitian yang dilakukan. Penyusunan kerangka pikir ini disusun berdasarkan dari hasil penelitian relevan [11], Pada kerangka berpikir yang penulis buat dapat di jelaskan sebagai berikut:

\subsection{Identifikasi Masalah}

Proses identifikasi masalah merupakan tahapan penulis untuk mengidentifikasi masalah yang ada pada objek penelitian. Tahapan ini merupakan tahapan penting untuk merumuskan permasalahan yang akan menjadi latarbelakang dalam penelitian yang dilakukan. Pada tahap ini juga merupakan tahap pengumpulan data.

\subsection{Analisis Kebutuhan Prototype}

Setelah data terkumpul, kemudian dilakukan analisa terhadap kebutuhan prototype baik dari kebutuhan pembuatan prototype seperti hardware dan software, kebutuhan pengguna, dan proses penganalisaan data dengan mengumpulkan beberapa data yang dibutuhkan.

\subsection{Perancangan Prototype}

Perancangan prototype pada penelitian ini adalah tahapan yang paling penting sebelum perakitan. Tahap perancangan ini terdiri dari apa saja yang dibutuhkan, fungsi dari komponen dan penempatan alat pada prototype yang akan dibuat. Perancangan pembuatan program sebelum ditranswer kehardware.

\subsection{Perakitan Prototype}

Setelah melakukan perancangan kemudian pada tahap ini yaitu perakitan prototype, pada tahap ini dilakukan pengcodingan dan pemasangan komponen - komponen rangkaian dalam bentuk hardware berupa prototype yaitu dengan mengaplikasikannya langsung pada sistem.

\subsection{Pengujian}

Pengujian dilakukan menggunakan running testing untuk mengetahui apakah hasil perancangan dan perakitan sudah sesuai yang diinginkan apa tidak dan seberapa besar kesalahannya. Kalau masih kurang sesuai kembali ke perancangan (Ramdhani, dkk. 2017).

Spesifikasi sistem pada penelitian kali ini dapat dilihat seperti pada Tabel 1.

Tabel 1 Spesifikasi sistem

\begin{tabular}{clc}
\hline No. & \multicolumn{1}{c}{ Nama Perangkat } & Jumlah (Unit) \\
\hline 1 & Arduino Uno & 1 \\
2 & LCD 2 x 16 & 1 \\
3 & Sensor Arus 30 Ampere & 1 \\
4 & Sensor Tegangan & 1 \\
5 & Port Jummper & 4 \\
6 & Kabel Jummper & 20 \\
7 & Adaptor 5 volt & 1 \\
8 & Swicth & 1 \\
\hline
\end{tabular}

Techno Vol. 20, No. 1, April 2019: $23-30$ 
Model skema sistem pengukuran tegangan dan arus dapat dilihat pada Gambar dibawah :

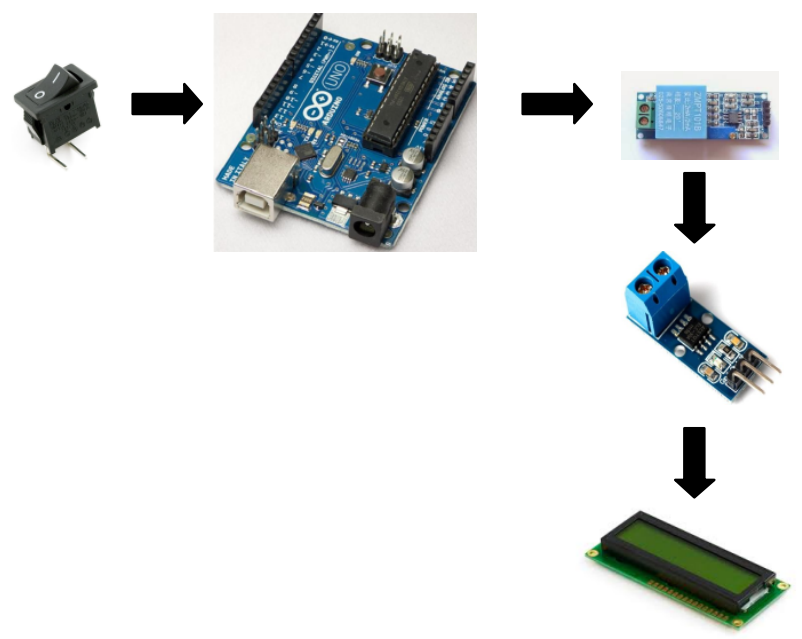

Gambar 1. Model skema sistem Pengukuran Tegangan dan arus.

Gambar 1 merupakan skema sistem pengukuran tegangan dan arus. Pada prinsip kerjanya, ketika power di On maka sumber tegangan ke board arduino uno sebagai sumber tegangan DC, sedangkan untuk sensor tegangan dan arus di hubungkan dengan penghantar listrik tegangan AC yang ada pada instalasi listrik, untuk sensor tegangan dihubungkan ke penghantar positif dan negatif sedangkan sensor arus hanya dihubungkan dengan ke penghantar positif saja. Setelah itu, sinyal akan diubah menjadi digital dengan menggunakan perangkat Arduino yang kemudian akan ditampilkan menggunakan Display.

\section{HASIL DAN PEMBAHASAN}

\subsection{Perangkat yang Digunakan}

1. Mikrokontroler Atmega 328

Mikrokontroler Atmega 328 adalah chip mikrokontroler 8-bit berbasis AVR-RISC buatan Atmel. Chip ini memiliki $32 \mathrm{~KB}$ memori ISP flash dengan kemampuan baca - tulis (read write), $1 \mathrm{~KB}$ EEPROM, dan 2 KB SRAM. Dari kapasitas memori Flash nya yang sebesar $32 \mathrm{~KB}$, itulah chip ini diberi nama ATmega328 [1]. Arduino merupakan rangkaian elektronik yang bersifat open source, serta memiliki perangkat keras dan lunak yang mudah untuk digunakan.

2. Sensor Arus dan Tegangan

ACS712 merupakan suatu IC terpaket yang mana berguna sebagai sensor arus menggantikan transformator arus yang relatif besar dalam hal ukuran. Pada prinsipnya ACS712 sama dengan sensor efek hall lainnya yaitu dengan memanfaatkan medan magnetik di sekitar arus kemudian dikonversi menjadi tegangan yang linier dengan perubahan arus [2]. Nilai variabel dari sensor ini merupakan input untuk mikrokontroler yang kemudian diolah. Keluaran dari sensor ini masih berupa sinyal tegangan AC, agar dapat diolah oleh mikrokontroler maka sinyal tegangan AC ini disearahkan oleh rangkaian penyearah.

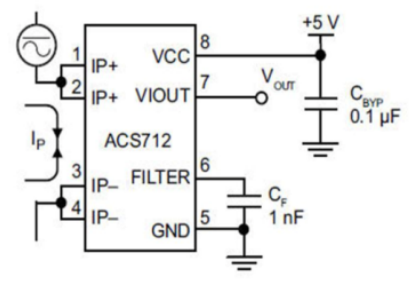

Gambar 2 Rangkaian Sensor Arus 
Spesifikasi dari sensor arus diatas dapat dilihat pada tabel 3 berikut.

Tabel 3 Spesifikasi Sensor Arus

\begin{tabular}{lcc}
\hline \multicolumn{1}{c}{ Karakteristik } & Simbol & RatingMaksimal \\
\hline $\begin{array}{l}\text { Tegangan } \\
\text { Suplai }\end{array}$ & Vcc & $8 \mathrm{~V}$ \\
$\begin{array}{l}\text { Ouput } \\
\text { Tegangan }\end{array}$ & Vout & $8 \mathrm{~V}$ \\
Toleransi & Ip & $100 \mathrm{~A}$ \\
ArusLebih & & $\begin{array}{l}\text { Tipe5T }=185 \mathrm{mV} / \mathrm{A} \\
\text { Tipe20T }=100 \mathrm{mV} / \mathrm{A}\end{array}$ \\
Sensivitas & & Tipe30T $=66 \mathrm{mV} / \mathrm{A}$ \\
\hline
\end{tabular}

Efek Hall adalah fenomena terdefleksinya aliran muatan pada keping logam yang diletakkan dalam medan magnet. didefleksi aliran muatan menyebabkan timbulnya beda potensial di antara sisi keping yang disebut potensial Hall.

Sensor tegangan menggunakan transformator tegangan sebagai penurun tegangan dari 220 ke 5 Volt AC kemudian disearahkan menggunakan jembatan diode untuk mengubah tegangan AC ketegangan DC, kemudian difilter menggunakan kapasitor setelah itu masuk kerangkaian pembagi tegangan untuk menurunkan tegangan, tegangan yang dihasilkan tidak lebih dari 5 Volt DC sebagai inputan ke mikrokontroler [2].

Regresi adalah pengukur hubungan dua variabel atau lebih yang dinyatakan dengan bentuk hubungan atau fungsi. Untuk menentukan bentuk hubungan (regresi) diperlukan pemisahan yang tegas antara variabel bebas yang sering diberisimbol $\mathrm{X}$ dan variabel tak bebas dengan simbul $\mathrm{Y}$. Pada regresi harus ada variable yang ditentukan dan variabel yang menentukan atau dengan kata lain adanya ketergantungan variabel yang satu dengan variabel yang lainnya dan sebaliknya.

Kedua variabel biasanya bersifat kausal atau mempunyai hubungan sebab akibat yaitu saling berpengaruh. Sehingga dengan demikian, regresi merupakan bentuk fungsi tertentu antara variabel tak bebas $\mathrm{Y}$ dengan variabel bebas $\mathrm{X}$ atau dapat dinyatakan bahwa regresi adalah sebagai suatu fungsi $\mathrm{Y}=\mathrm{f}(\mathrm{X})$. Rangkaian sensor tegangan dapat dilihat pada gambar berikut :

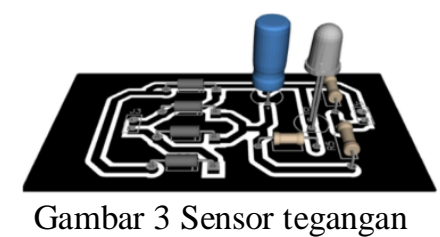

\subsection{Pembuatan Perangkat}

Pembuatan perangkat sistem monitoring tegangan dan arus pada tegangan AC atau arus searah menggunakan Arduino Uno, LCD, sensor tegangan 220 sampai 250 Volt/ AC dan sensor arus dengan kapasitas 30 Ampere. Semua komponen tersebut dirangkai menjadi satu kesatuan.

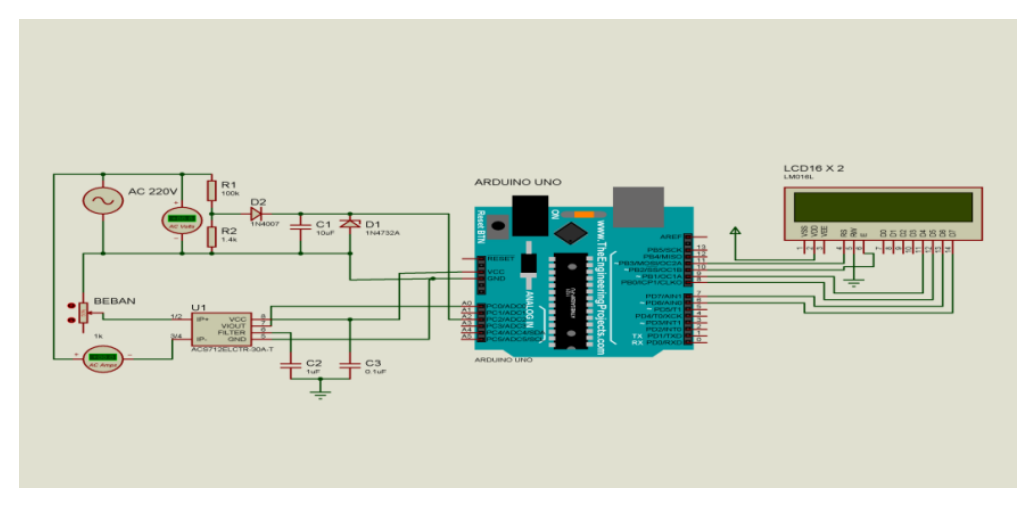

Gambar 5. Rangkaian sistem 


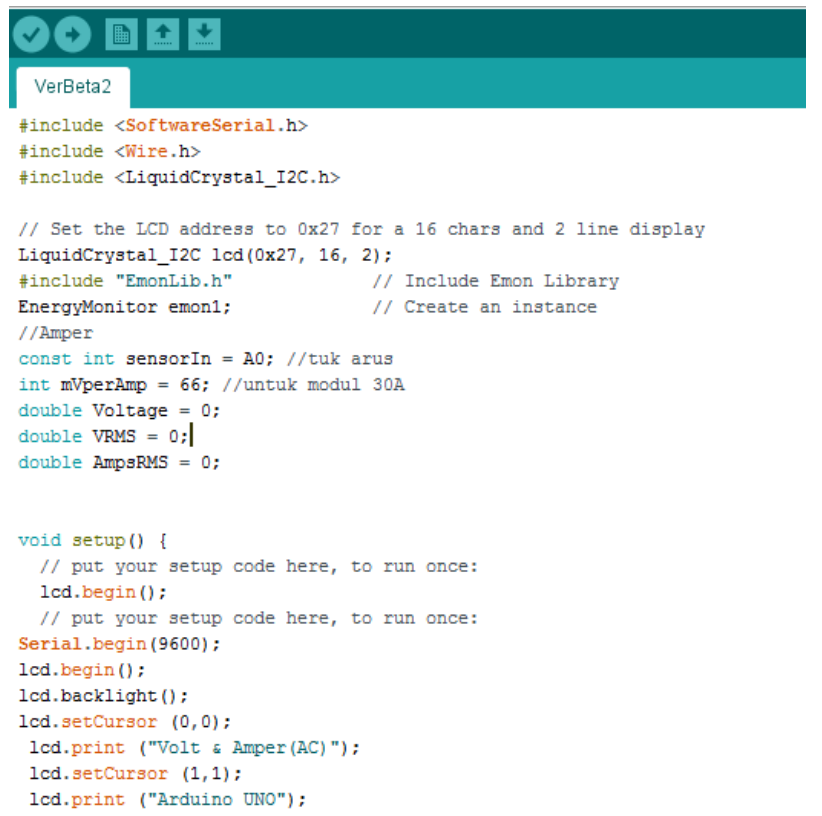

Gambar 6. Pemrogram Arduino

\subsection{Pengujian Perangkat}

Pengujian perangkat ini untuk mengetahui kerja alat dengan cara melakukan running test. Perangkat yang telah di rangkai sesuai dengan skema pada Gambar 5 ini di uji untuk mengetahui apakah perangkat tersebut bekerja sesuai dengan sistem yang diinginkan. Running test ini dinyatakan berhasil apabila LCD akan berubah tampilannya. Jika untuk mengukur tegangan maka yang ditampilkan oleh lcd adalaha AC Volt untuk tegangan $\mathrm{AC} /$ arus searah dan untuk pengukuran arus lcd yang tampil adalah $\mathrm{AC} \mathrm{Amp}$ untuk arus searah.

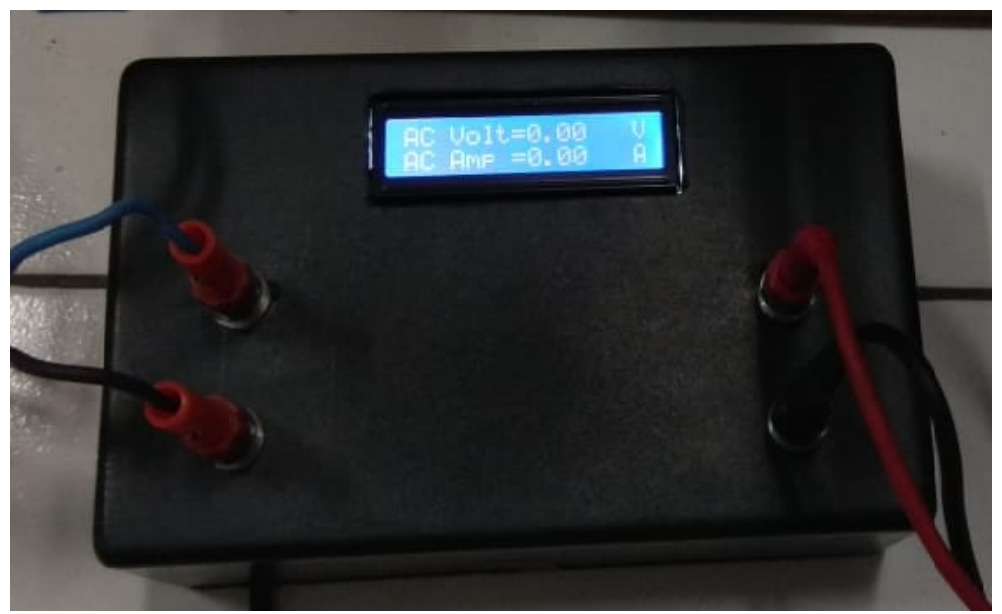

Gambar 7. Proses pengujian perangkat 


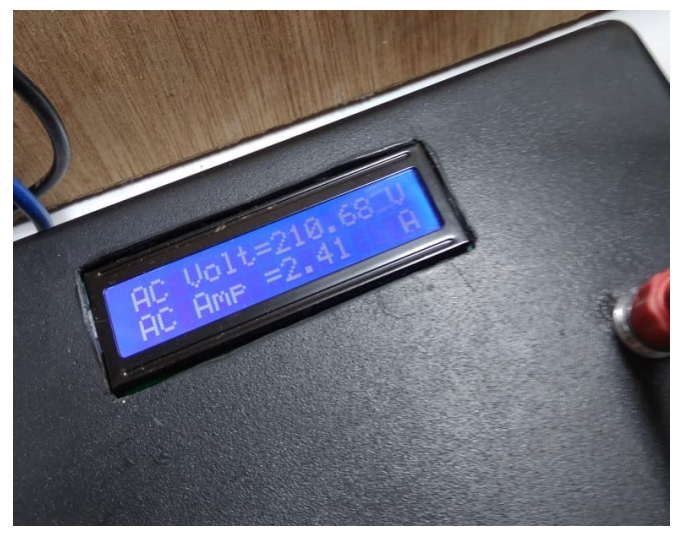

Gambar 8. Hasil Pengukuran perangkat

\subsection{Hasil Pengujian}

1. Daya $450 \mathrm{VA}$

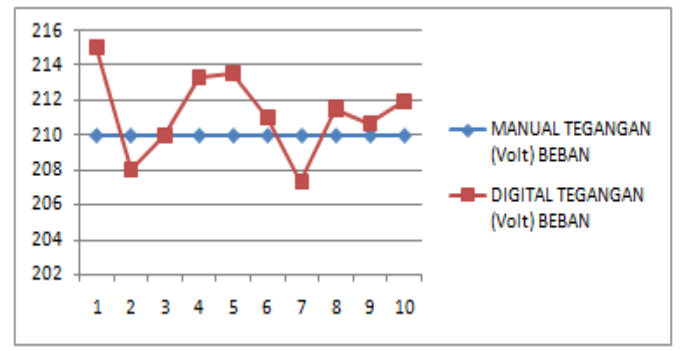

Gambar 9. Pengukuran Tegangan dengan Beban

Dari hasil pengukuran daya 450 VA dapat disimpulkan bahwa hasil pengukuran tegangan dengan menggunakan beban secara kesulurahan pengukuran tegangan mengalami penurunan, sedangkan pengukuran arus mengalami kenaikan baik pengukuran secara analog maupun digital.

2. Daya $900 \mathrm{VA}$

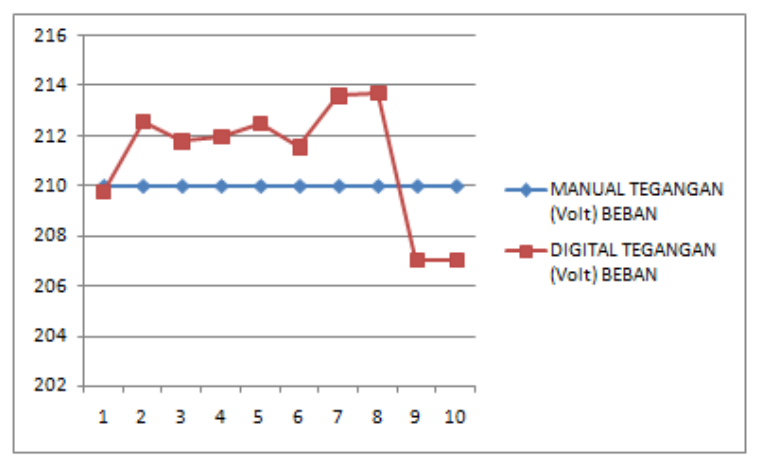

Gambar 10. Pengukuran Tegangan dengan Beban

Dari hasil pengukuran daya 900 VA dapat disimpulkan bahwa hasil pengukuran tegangan baik yang terbeban maupun yang dibebani secara kesulurahan tegangannya tidak mengalami penurunan yang sangat signifikan, sedangkan pengukuran arus mengalami kenaikan pada pengukuran secara digital, hal ini pembacaan secara digital lebih presisi dan akurat. 
3. Daya 1300 VA

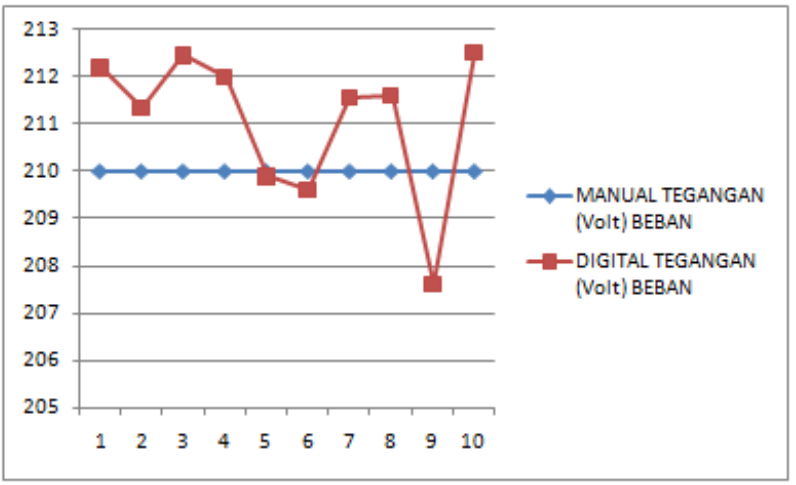

Gambar 11. Pengukuran Tegangan dengan Beban

Dari hasil pengukuran daya 1300 VA dapat disimpulkan bahwa hasil pengukuran tegangan baik yang terbebani mengalami penurunan pada percobaan yang ke 9, sedangkan pengukuran arus mengalami penurunan pada pengukuran secara digital.

4. Daya 2200 VA

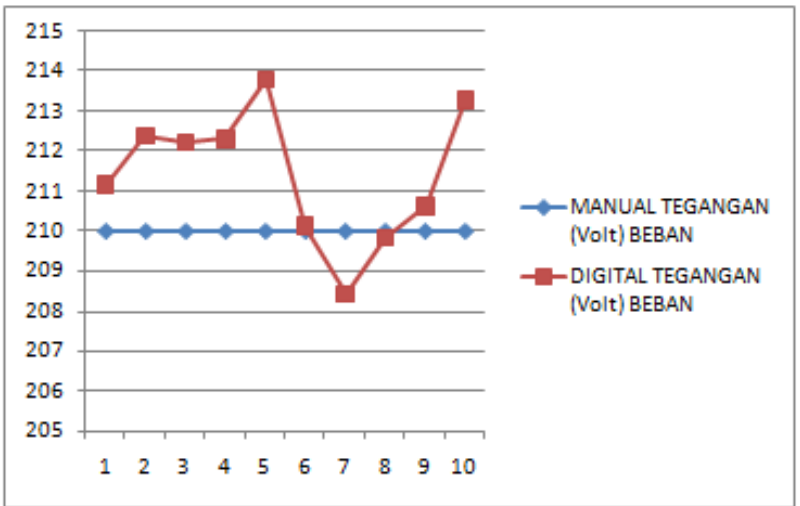

Gambar 12. Pengukuran Tegangan dengan Beban

Dari hasil pengukuran daya 2200 VA dapat disimpulkan bahwa hasil pengukuran tegangan baik yang terbebani mengalami penurunan pada percobaan yang ke 7 .

\section{KESIMPULAN (10 PT)}

1. Hasil Pengukuran dengan cara pengukuran secara analog dan digital berbeda hasilnya, hal ini di karenakan pada pembacaan alat ukur analog tidak dapat membaca nilai dengan satuan terkecil sedangkan pengukuran secara digital dapat membaca nilai satuan terkecil sehingga lebih presisi dan akurat.

2. Pada hasil pengukuran tegangan pada output digital didapatkan nilai yang tidak stabil ini bisa disebabkan oleh pengaruh nilai presisi pada saat pemrogramannya,

3. Pengukuran arus secara digital ada kenaikan yang signifikan dimana menunjukan kenaikan antara 0,5 Ampere sampai 2 Ampere.

\section{DAFTAR PUSTAKA (10 PT)}

[1] Arduino, 2016, Arduino Uno Board, https://www.arduino.cc/en/ Main/ Arduino Board Uno,diakses 11 Februari 2016.

[2] Belajararduino.com/sensor-arus-acs712-arduino [Online 1 Februari 2017] http://belajararduino.com/sensor-arusacs712-arduino/

[3] Elektronika-dasar.web.id/lcd-liquid-cristal-display Online 1 Februari 2017] http://elektronika-dasar.web.id/lcdliquid-cristal-display/ 
[4] Fatoni, Nugroho, Irawan. 2015. Rancang Bangun Alat Pembelajaran Microcontroller Berbasis Atmega 328 Di Universitas Serang Raya. Jurnal Prosisko. Vol 2. No.1. maret. ISSN: 2406-7733.

[5] Feynman, Richard (1970). Feynman lectures on physics. Boston, MA: Addison Wesley Longman. ISBN 978-0201-02115-8.

[6] https://www.guru pendidikan.co.id/ pengertian rumus dan satuan energy listrik beserta contoh soalnya lengkap

[7] Introduction of ACS712 Current Sensor Module - 30A With Arduino, September 2016.

[8] Isma, Amrullah. Dkk. 1985. Studi Pengembangan Sistem Kelistrikan Kota Watampone

[9] Marsudi, Djiteng “ Operasi Sistem Tenaga Listrik” Yogyakarta, 2006

[10] Nuryaman, Mulyana, Mardianti. 2017. Rancang Bangun Prototipe Alat Pengukur Kecepatan Kendaraan Dengan Sensor Infra Merah. 15-16 Desember 2017, pp. 345-366. ISBN: 978-602-512-810-3.

[11] Ramadhani, A.S., Aminudin, A., Danawan, A., 2017. Rancang Bangun Sistem Pengukur Kecepatan Kendaraan Menggunakan Sensor Magnetik. Ejournal.upi.edu. 28-36. E-ISSN:2549-1989.

[12] Robert A. Pelcovits; Joshua Farkus (2008). Barron's AP Physics C: Advanced Placement Examination. Barron's Educational Series. hlm. 174. ISBN 978-0-7641-3710-5.

[13] Sugiyono. 2012. Metode Penelitian Kuantitatif, kualitatif dan R \& D. Bandung:Alfabeta

[14] Teknik elektronika.com/rumus-rangkaian-pembagi-tegangan-voltage-divider-resistor [Online1Februari 2017] http://teknikelektronika.com/rumus-rangkaian-pembagi-tegangan-voltage-divider-resistor/

[15] Wardoyo, Siswo, dan Anggoro Suryo Pramudyo.2015. Pengantar Mikrokontroler dan Aplikasi pada Arduino. Yogyakarta: Teknosain. 